I hope the Hospital Advisory "Service (Supplement, 5 July, p. 5) will be successful, but by reporting direct to the Minister, in whose sole discretion implementation will lie, the service would seem to lack independence in drawing public attention to what requires to be done in matters of hospital accommodation. What are of greater importance to the individual patient and relative are care and treatment, and the lack of an impartial and independent body in England to oversee this aspect is a sad gap in the mental health service.-I am, etc.,

Hugh Rose.

Edinburgh 9. REFERENCE

Royal Commission on the Law Relating to Mental Illness and Mental Deficiency, 1957. London, H.M.S.O.

\section{Doctors' Own Diseases}

SIR,-During the course of my recovery from a painful but happily not incapacitating disorder I have examined descriptions of the symptoms in a number of standard textbooks. I find all of them completely inadequate. It has therefore occurred to me that a book consisting of descriptions of diseases written by doctors who have suffered from them might be of value. Heinemann Medical Books Ltd. propose to publish such a book provided sufficient material is available.

I would be glad if any of your readers who have suffered from any disorder would write a detailed description of their symptoms and the effects of treatment, and send the manuscript to me care of William Heinemann Medical Books Ltd., 23 Bedford Square, London W.C.1.-I am, etc.,

London W.

RAYMOND GREENE,

William Heinemann Medical Books Ltd.

\section{Cancer from Mineral Oil}

SIR,-I think we should be reminded that nearly 50 years ago Alexander Scott (obituary, 24 November, 1956, p. 1244) in his M.D. thesis to the University of Glasgow associated mineral oil as a cause of cancer of the scrotum. He was then a practitioner in Broxburn, where in his day mineral oil known as "paraffin" was sold to the public. I think his name deserves a place in the bibliography of cancer.-I am, etc.,

Kilmacolm, Renfrew.

$$
\text { W. LEONARD FORSYTH. }
$$

\section{REFERENCE}

2. Scott, A., in 8th Scientific Report on the Investi gations of the Imperial Cancer Research Fund, 1923, p. 85 .

\section{Feeding the Newly-born in Hospital}

SIR,-Your leading article concerning the feeding of premature babies (25 October, p. 186) leaves open the final choice but condemns extremes in protein content. One mundane consideration which influences paediatricians in practice is the effect upon the chosen feed of terminal heat treatment in the hospital central milk kitchen autoclave. If this results in a homogeneous suspension becoming a composite of butter whey, and curd, which needs warming and shaking to make palatable, we may be per- suaded to use either an evaporated or an adapted milk, both of which hold together better than the popular brands of dried cow's milk. An alternative solution is now available in the ready-to-feed commercial products which offer durability and unvarying composition, but at a price. There may not be a best feed in biological terms as an alternative to breast milk for the newly born in hospital, but expediency may well dictate the choice.-I am, etc.

Royal Infirmary,
Hull, Yorks.

R. J. PugH

\section{Iatrogenic Dermatitis}

Sir,-In reply to Dr. I. B. Sneddon's question (4 October, p. 49) both the mother and daughter we described ${ }^{1}$ had been using potent steroid applications prior to attending our department. We have perused the notes

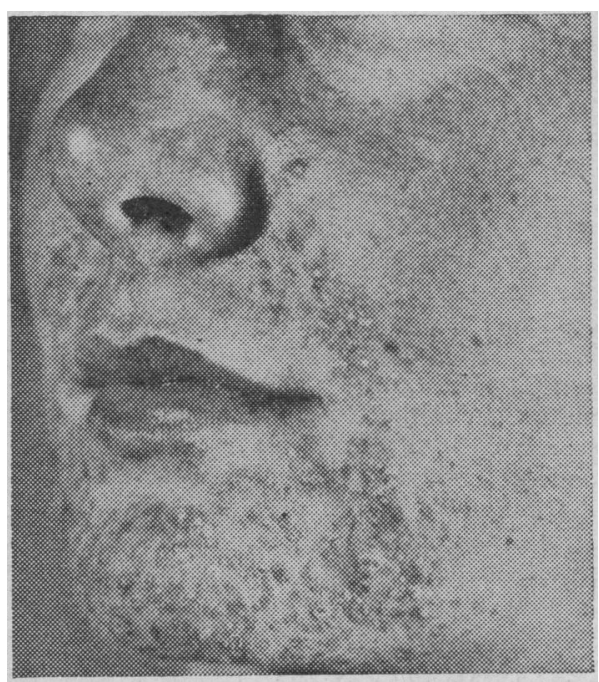

of seven other patients seen with perioral dermatitis since 1968 (six females, one male) and six of these had been using fluocinolone acetonide or betamethasone valerate prior to seeing us. The one patient who had no used fluorinated steroids had used an ointment containing hydrocortisone and she presented with a typical perioral eruption. All our patients, including the mother and daughter, have responded slowly but well to treatment, which has usually been a sulphur containing cream often preceded by a hydrocortisone-containing preparation.

We, too, have experienced difficulty in persuading patients to stop using stron steroid applications, and the continued and sometimes surreptitious use of these preparations may account for resistance to treatment in some cases. It seems clear that potent topical corticosteroids contribute to the chronicity of this condition and it is now well recognized that prolonged use of such preparations-for example, in rosacea, seborrhoeic dermatitis, acne, psoriasis-do produce a detrimental but usually reversible effect on the facial skin.

We did not see our patients prior to treatment with these applications and can only speculate on the nature of the original skin condition. We accept that withdrawal of topical corticosteroids is one cause of a perioral dermatitis, but, as Dr. Sneddon mentions, the condition was seen before potent topical steroids were available, and Dr. Peter Borrie has kindly shown us a photograph (see Figure) of a patient he saw in 1951, a time when even local hydrocortisone was not in general use.-We are, etc.,

JULIAN Verbov. EDWARD ABELL.

Department of Dermatology, London E.C.1.

REFERENCB Verbov, J. L., and Abell, E., British fournal of
Dermatology, 1968, 80, 695.

\title{
Anticoagulant Therapy
}

SIR,-Recently we transferred some of our anticoagulated patients from phenindione to warfarin because there is evidence that the latter drug is safer. ${ }^{1}$ It is generally accepted that approximately $10 \mathrm{mg}$. of phenindione is equivalent to $1 \mathrm{mg}$. of warfarin and 12 of our patients were accordingly changed to the equivalent dose of warfarin (see Table). Quick's one-stage prothrombin times were

Initially all the patients, with the exception of Nos. 2 and 11, had prothrombin ratios which lay within a corrected range of activity determined by the current Manchester Comparative Thromboplastin and were reasonably well stabilized. A repeat prothrombin ratio was obtained several days after the transfer to warfarin and these results are shown in the Table. Figures in parentheses show the

\begin{tabular}{|c|c|c|c|c|c|c|}
\hline Patient & $\begin{array}{c}\text { Sex and } \\
\text { Age }\end{array}$ & $\begin{array}{c}\text { Prothrombin } \\
\text { Ratio }\end{array}$ & $\begin{array}{c}\text { Daily } \\
\text { Phenindione } \\
\text { Dosage (mg.) }\end{array}$ & $\begin{array}{c}\text { Daily } \\
\text { Warfarin } \\
\text { Dosage (mg.) }\end{array}$ & $\begin{array}{c}\text { Post-Warfarin } \\
\text { Prothrombin } \\
\text { Ratio }\end{array}$ & $\begin{array}{c}\text { Restabilized } \\
\text { Daily Warfarin } \\
\text { Dosage (mg.) }\end{array}$ \\
\hline $\begin{array}{r}1 \\
2 \\
3 \\
4 \\
5 \\
6 \\
7 \\
8 \\
9 \\
10 \\
11 \\
12\end{array}$ & $\begin{array}{ll}M & 51 \\
\mathrm{~F} & 56 \\
\mathrm{M} & 48 \\
\mathrm{M} & 53 \\
\mathrm{~F} & 74 \\
\mathrm{~F} & 34 \\
\mathrm{M} & 65 \\
\mathrm{M} & 56 \\
\mathrm{M} & 47 \\
\mathrm{~F} & 42 \\
\mathrm{M} & 44 \\
\mathrm{M} & 55\end{array}$ & $\begin{array}{l}2 \cdot 3 \\
1 \cdot 7 \\
2 \cdot 4 \\
2.9 \\
2.0 \\
2.7 \\
1.9 \\
1.9 \\
2.3 \\
1.8 \\
1.7 \\
1.9\end{array}$ & $\begin{array}{r}175.0 \\
112.0 \\
62.5 \\
100.0 \\
112.5 \\
50.0 \\
100.0 \\
62.5 \\
50.0 \\
62.5 \\
177.0 \\
137.5\end{array}$ & $\begin{array}{r}17.50 \\
11.25 \\
6.25 \\
10.00 \\
11.25 \\
5.00 \\
10 \cdot 00 \\
6.25 \\
5.00 \\
6.25 \\
17.50 \\
13.75\end{array}$ & $\begin{array}{l}4 \cdot 8(17) \\
5 \cdot 3(15) \\
4 \cdot 0(27) \\
2 \cdot 7(14) \\
6 \cdot 7(28) \\
3 \cdot 0(12) \\
3 \cdot 5(24) \\
1.8(16) \\
5 \cdot 0(12) \\
2 \cdot 2(23) \\
2 \cdot 5(21) \\
3 \cdot 4(19)\end{array}$ & $\begin{array}{r}10 \cdot 00 \\
3.00 \\
5.00 \\
6 \cdot 25 \\
5.00 \\
7.50 \\
7.50 \\
7 \cdot 50 \\
3.75 \\
6.25 \\
17.50 \\
6.25\end{array}$ \\
\hline
\end{tabular}

performed using human brain thromboplastin, and prothrombin ratios were calculated and corrected according to the Manchester Comparative Thromboplastin (18 October, p. 125). number of days elapsing between changing the drug and obtaining the first post-warfarin prothrombin ratio. It will be seen that the post-warfarin ratios were higher in 10 patients and outside the upper limit of the "thera- 